\title{
Concept of Dāna through the Specturm of the Garuḍapurāna and its Impact on the Present Day Society
}

\author{
Jumli Nath
}

\begin{abstract}
The Garudapurāna is one of the most important Sāttvika Purāna which closely deals with all kinds of ethical values viz., dāna, vrata, ācāra, vyāvahāra, prāyaścitta, āśauca etc. This Purāna continues to be a perpetual source of inspiration, awakening the intellect of the human society and thereby exert influence on the religion of the people. Puranic literature carries perennial message for the welfare of the mankind. The Garudapurāna is encyclopaedic in nature and embraces a vast range of subjects like āyurveda, jyotișa, astronomy, metrics, grammar, religion and philosophy, cosmogony, the knowledge of supreme Brahman, rebirth, karman, geography, politics and the like. It is also an abstract of Dharmaśāstra which deal with ācāra, vyāvahāra, prāyaścitta, dāna, āśauca etc. All these are some directive complementary to each other which regulate the behaviour of human conduct in a right way and therefore these are the principal objects of discussion in Dharmaśāstra literature. Among these different topics of Dharmaśästra, the Dānadharma has great spiritual and moral value in the Hindu society because it has been playing an important role in moulding the character and behaviour of the people of our country through ages. Dāna or charity means to give anything forever without any expectation of return. It is regarded as the best form of dharma which promotes the high ideal of human values. It is one kind of help and act of giving or sharing anything with others without a selfish motive or desire for its results with the intention of welfare or to help. It benefits both the giver and receiver and promotes peace and harmony in the society by favouring economic equilibrium. In the Garudapurāna four types of dāna are mentioned. These are nitya (daily), naimittika (occasional), kāmya (made with the desire of fruits) and vimala (pure or disinterested). All these have great numerous values in the society of the time of Garudapurāna. Here, in this paper, a modest attempt is made to highlight the value of dānadharma and its impact on society through the spectrum of Garudapurāna.
\end{abstract}

KEY WORDS: Garuḍapurāna, dāna, nitya, naimittika, kāmya, vimala etc.

\section{INTRODUCTION}

Ancient Indian culture and civilization was based on values. In old Indian scriptures we find domination of values in every sphere of human life. Values help in the maintenance of peace of harmony. It stands for ideals of life. These are the principles that lay a solid foundation for a civilized and

Revised Manuscript Received on October 22, 2019

Dr Jumli Nath, Department of Sanskrit, Gauhati University, Guwahati, India

Email id jumlinath770@gmail.com

carrying society. At the present time there is a need for inculcation of values because of diminishing influence of religion, absence of moral education etc. that create an unexpected erosion in the values of younger generation. The Puranic literature carries a perennial message for the welfare of the mankind. Puranic literature provides guidelines and instructions to the mankind for inculcating all kinds of human values containing virtues which have immen se values in the life of human society. The Purānas played an important role in bringing the followers of the different religious cults into a composite the society. Purānas is the result of the greatest effort of the Vyāsa made to conserve all ancient beliefs, traditions of the race in a very collected form. It is the Purānas that which have brought about unity in diversity, taught religious toleration of the followers of different faiths by making them realize that God is one, though called by different names. Among all Purāṇas the Garuḍapurāna is the most important one which continues to be a perpetual source of inspiration, awakening the intellect of the human society and thereby which influence on the religion of the people is profound. The Purānas played an important role in bringing the followers of the different religious cults into a composite the society. Purānas is the result of the greatest effort of the Vyāsa made to conserve all ancient beliefs, traditions of the race in a very collected form. It is the Purānas that which have brought about unity in diversity, taught religious toleration of the followers of different faiths by making them realize that God is one, though called by different names. The Garuḍapurāṇa is one of the most prominent Vaiṣnava Purāṇa for which it is enumerated in the list of Sāttvika Purāna.

The Purāṇas deal with ceremonies, customs, ācāra, vyāvahāra, prāyaścitta, dāna and so many other aspects of the Hinduism. All these are some directives complementary to each other which regulate the human conduct in a right way. For the study of the samskāras the Purānas are not less important than the Epics. Their influence on the Dharmaśāstra literature is immense. Even the earliest Dharmasūtras bear witness to the popularity of the Purānas which they often quote. They are in many ways connected with Smrtis and they contain large sections of traditional

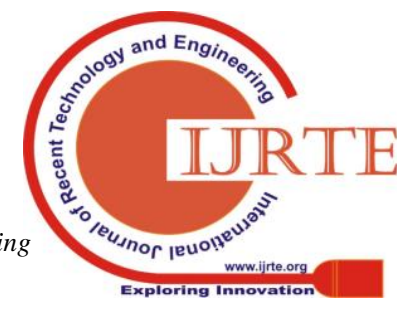


materials from the Dharmasūtras, focusing particularly on the rules of conduct (ācāra) that constitue Varṇāśrama-dharma, Dāṇadharma, sins, penance and the like. The Garuḍapurāna specially refers to the Yājñavalkyasmṛti and Parāśarasmṛti. In the Dharmaśāstra section of this Purāna, we find a brief description of Varṇadharma, Āśramadharma, Dānadharma etc. Among these, Dānadharma has great spiritual and moral value in the Hindu society, because it has been playing an important role in moulding the conduct and character of the people of our country through ages.

\section{ETHICAL VALUES REFLECTED IN THE GARỤ̣APURĀṇA}

The Garuḍapurāna speaks all kinds of ethical values. It teaches us about the concept of equanimity viz., seeing god in each soul, compassion etc. Dānadharma , various kinds of vrata, virtuous conducts, satisfaction, belief in God, devotion, forbearance, truthfulness, charity, purity of body and mind, curbing the organs of the senses, worship of deities, offering into fire, satisfaction, ahimsā etc., are various kinds of ethical values reflected in the Garuḍapurāna. The practitioner of ethical values like dānadharma, vrata, ahimsā, dharma etc helps a man to find peace, joy, strength and tranquility within himself. His life becomes thoroughly disciplined. Actually non-violence, truth, non-stealing, cleanliness and control of the senses are the common duties to all men. A list of idealized moral virtues for producing superior types of men in society is given as viz., satya, brahmacharya, śruta, tapas, dharma, kriyā, yajna, ayus, rūpa, bala, medhā, arogya, dāna etc.

Dānadharma increases various kinds of ethical values like spiritual, moral values etc. of the individuals. For carrying peace and harmony in the society, mutual love, unity, integrity etc. are indispensable component which can be said as the foundation of supporting nonviolence. The performance of a sacrifice is incomplete and useless without dāna. Dāna means giving something to those who is in need with a view to help without any selfish motive. Dāna clearly indicates the moral obligation on the part of a gift-maker towards the need of the society.

Among all ethical values, dāna is considered as the best value. Hindu texts describe it as a virtue and duty of every person. It is the best form of dharma. Here, in this paper, a modest attempt is made to highlight the ethical value of dānadharma and its impact on society through the spectrum of Garuḍapurāṇa.

\section{DEFINITION OF DĀNA:}

Dāna is considered an act of compassion and must be done with no desire of material gain. It is the best form of dharma. The performance of a sacrifice is incomplete and futile without dāna. Dāna means giving something to those who is in need with a view to help without any selfish motive. Dāna consists in the cessation of one's ownership over a thing and creating the ownership of another over that thing and this last occurs when the other accepts the thing 1.The meaning of the term clearly shows that the term indicates the moral obligation on the part of a gift-maker towards the needy of the society who are bonafide for receiving it. According to Manu, dāna is the highest virtue in the Kaliyuga2 (the iron age). The Garuḍapurāna also says dāna yields enjoyment and emancipation 3. It has been one of the means of expiating sins in Dharmaśāstra literature 4.

\section{DIVISIONS OF DĀNA :}

The Garuḍapurāṇa refers four types of Dāṇa. These are nitya(daily), naimittika (occasional), kāmya (made with the desire of fruits) and vimala (pure and disinterested) 5. The nitya type of Dāṇa takes place when donations are made to Brāhmaṇas without expecting anything in return. When donations are made as penance or to take care of ill omens, it is known as naimittika dāna. The kāmya type of dāna takes place when donations are made to attain children, victory or wealth, while vimala variety of dāna consists of donations made simply for the sake of pleasing god 6. Dāna is the essential practice of cultivating generosity. Padma purāna also deals with concept of dāna and as well as its core parts. 7 But there exists slight variation in both the Purānas. Padmapurāṇa also states about the concept of prāyika-dāṇa, which is called as vimala dāna in the Garudapurāna. In Padmapurāna we found about the ten means of punyas which are the means of good deeds through the speech of Mātali. Ten means of Punyas are stated are ahimsā (non-violence), kṣamā (forgiveness), satya (truthfulness), lazzā (modesty), śraddhā (patience), indriya samyam (self-control), dāna (charity), yagna (sacred rituals), dhyāna (meditation), jňān (knowledge). Eight types of main Charity are of anna, jala, horse (vāhana), cow, vastra, shayya (bed), sutha (cotton ), and āsana (seat). Anna dāna is stated to account for half of all kinds of dāna. Jala dāna is of next best importance. Together, these two accounts for the best part of dānas8. The feeling of dāna gradually increases the feeling of non harming to nobody. Among the punyas, meditation and jnān occupy prominent position which helps to promote the feeling of Ahimsā in the minds of people. 
It is the Agnipurāna that speaks of ten virtues that must be followed as common to all vratas, viz., forbearance, truthfulness, compassion, charity, purity of body and mind, curbing the organs of the senses, worship of deities, offering into fire, satisfaction and not depriving any other of his belonging. The central point of vrata is upavāsa i.e. fasting 9. Moreover, the Bhāgavatapurāna also states the concept of dāna slight differently. In Book 8, Chapter 19, verse 36 it states that charity is inappropriate if it endangers and cripples modest livelihood of one's biological dependents or of one's own. It says dāna is called as proper when it is improper. Dāna from surplus earnings above that required for modest living is recommended in the Bhāgavatapurāna.10 The concept of dāna of all the Purāṇas has a similar tone. Though the concept of dāna of Garuḍapurāṇa is same like other Sāttvika Purāṇas.

In the Bhagavtagitā also the concept of dāna is elaborately stated. As per Bhagavtagitā, there are three types of gift or charity which depends on three modes of Prakrti or the primal matter. Bhagavtagitā states dāna or charity as a part of duty in human life. Besides, it says that charity is referred to as born of sattva which gift is given with the idea that it ought to be given, to one who will not serve11 in return, and at the (proper) place, (proper) time and to a (proper) person. Charity is given with desires of return. But the charity which is given expecting reciprocation, or again, with a desire for its result, and which is given unwillingly, that is considered to be born of rajas.12 The charity which is made at an improper place and time, and to undeserving persons, without proper treatment and with disdain, is declared to be born of tamas. 13Charity is wrongly given due to ignorance of the people.

\section{V.TIMES OF DĀNA:}

According to the Garudupurāna the times for performing the dāna are as follows- the full-moon day in month of Vaiśākha, the twelve day of the fortnight, the equinox, the solar and lunar eclipses and on the last day of month etc14. These are the some occasions in where dāna is to be performed.

\section{ARTICLES OF DĀNA:}

Garuḍapurāṇa also says about the articles of dāna. The articles of dāna are like land, house, honey, cakes of sesamum seeds, scents, water, boiled rice, lamps, gold, silver, horse, bulls, conveyances, beddings, umbrella, cloths, clarified butter, paddy, garland of flowers, trees, a carriage of clarified butter, Vedas and the like. Besides these a thousand of milch-cows with their horns cased in gold and hoops bound with silver may be given in gift to a Brāhmaṇa with thousand bowls of Indian bell metal15.

\section{VII.RECEIVER OF DĀNA}

Again Garuḍapurāṇa states about the receivers of dāna. The articles of dāna are basically provided for Brāhmaṇas in ancient times. Brāhmaṇas are considered as the fittest persons to make gifts to, the foremost among them being those who regularly perform and celebrate the Brāhmanical rites and ceremonies. The best even among the later are those who know the Supreme Brahman and have devoted themselves to the cultivation of intellectual and spiritual knowledge. A gift should be made every day to a worthy receiver as well as on special occasions. A person is normally bound to give something in charity to a person in straitened circumstances and soliciting his help, according to his own means and in a devout spirit 16.

The ethics of the dāna consist in the fact that it benefits both the giver and receiver, while it humanized and sublimate the giver and materially benefits the receiver. The recipients must be orthodox Brahmins for merit to be attained, because only they are ordained to receive donations (because they recite Vedas daily which has power to repel sins that are inevitably attached to any donation). Thus dāna works for reducing the poverty, and produces equality in the society. It can be also noticed that almost all the vratas dāna is made to the brāhmana caste only. The reason is seemed to be that the other varnas were capable of doing any kind of works but brāhmanas are not permitted to do all those. They have to live only by mainly performed rituals. Hence they are given dānas to survive in society. Thus vrata through dāna promotes peace and harmony among all the caste in the society by favouring equilibrium. Hence the vratas in the Garudapurāna are not just an oblation to Gods and goddessess, rather it is directly concerned with the social and moral life of the people.

\section{VALUES AND MERITS OF DĀNA OR CHARITY :}

The Garuḍapurāna deals with dānadharma which prescribes some moral codes need for society. Dāna is a pious activity which promotes the high ideal of human values, because it is the basis of the ethical, moral and spiritual aspects of human behaviour which guides and inspires a man to act in a righteous way. Morality presupposes righteousness. The Garuḍapurāṇa declares that what is given in this world as a gift, it is beneficial both to the giver and the receiver. Dāna promotes peace and harmony in the society. Besides these it also helps a man to achieve the ultimate goal of human life, i.e. the knowledge of Brahman which leads to the path of liberation. The realization of Brahman makes a man noble, perfect and creates a power for humanity. Thus, Dānadharma 
has been occupying a prominent place in the Indian society through ages.

Dānadharma has great ethical value in our life which promotes nonviolence in our life. Dānadharma occupies a highest place among all the Samiskāras which a human being should obey throughout his life and the Garuḍa Purāna occupies an important position among all the Purānas while promoting Dānadharma for uplifting of individual as well as social life of the people which is the basis of promoting the concept of nonviolence in the society.

Garuḍapurāṇa mentions about the numerous merits of dāna. It is said that if a man gives lands abounding in barley and corns and out skirted on all sides with sugarance plants, he is never born again 17.By giving education or food to the Brāhmaṇas, one becomes glorified in the region of Brahmā 18. If a person, after fasting on the full-moon day in the month of Vaiśākha, adores twelve Brāhmaṇas with honey and cakes of sesamum seeds or with scents or with sweet and moral words, all the sins committed by him all through his life, are immediately dissipated 19 . He who specially in the month of Vaiśākha treats the Brāhmaṇas with clarified butter, boiled rice and water in honour of Dharmarāja, becomes free from all fear. If on the twelfth day of fortnight a person adores Viṣnu who destroys all sins he becomes freed from all sins 20. The giver of water attains gratification. The giver of boiled rice enjoys happiness. The giver of lamps obtains most excellent eyes 21 . One who gives away lands attains everything, while a giver of gold acquires longevity. The giver of houses attains the most exalted station in the world and the giver of silver a most handsome appearance 22. The giver of corns enjoys eternal happiness; while the giver of Brahma (knowledge of) attains the neighbourhood of Brahmā 23.

It is further stated that making the gift of a house or paddy, umbrella, garland of flowers, or of tree and water ensures an exalted position to the giver in heaven 24 .

The Garuḍapurāna also highly praises the gifts of cows. It is said by the Purāna that a gift-cow should have its horns and hoofs tipped with gold and silver respectively. A person who makes such a gift stays in heaven. Similarly the Garuḍapurāna attaches special importance to the gift of a cow when she is due to give birth to a calf and donor is said to stay in heaven 25. But the best article of donation is a piece of land.

Thus the Garuḍapurāṇa mentions varied and variegated gifts and their rewards . Moreover, from what has been discussed till now, it can be gathered that all the necessary and desirable things of life are recommended by this Purāna for gift giving to Brāhmaṇas and worthy persons.

\section{IMPACT OF DĀNA IN PRESENT DAY SOCIETY}

From the earliest epochs of the Indian cultural traditions charity has been considered as a very noble aspect of human character. It was one of the important duties the individual had to perform. It increases spiritual and moral values of the individuals. The Purānic literature constitutes a major part of religious literature of India and they are a meeting point of diverse religious and social beliefs and represent a synthesis of various cultural tradition. For the upliftment of our society mutual love, unity and integrity are indispensable and the act of giving goes a long way to materialise these feelings. The Garuḍapurāṇa deals with Dānadharma and prescribes some moral codes for society. Dāna is a pious activity which promotes the high ideal of human values, because it is the basis of the ethical, moral and spiritual aspects of human behaviour which guides and inspires a man to act in a righteous way. In the Purāṇas, ethics and religion are shown to be in an intimate relation and both have humanistic ideals. Morality presupposes righteousness. The Garuḍapurāna declares that what is given in this world as a gift is received in the other world by the way of merit. So, dāna has great religious significance in our society. In a society the individuals depend on one another. It is therefore, imperative that men dedicate their life for the good of humanity at large, to the best of capacity, without any selfish motive. Hence, it is the duty of a wealthy person, to share some part of his property with those who are less privileged. Then it is beneficial both to the giver and the receiver. Dāna promotes peace and harmony in the society by favouring economic equilibrium. Dāna also helps to a considerable extent in developing philanthropic tendencies among people. Besides these it also helps a man to achieve the ultimate goal of human life, i.e. the knowledge of Brahman which leads to the path of liberation. The realization of Brahman makes a man noble, perfect and creates a power for humanity. Thus, Dāṇadharma has been occupying a prominent place in the Indian society through ages.

\section{X.CONCLUSION}

From the forgoing discussions, it is clear that Dānadharma has great ethical value in our life.

Charity is held as a noble deed in Hinduism, to be done without expectation of any return from those who receive the charity. Some texts reason, referring to the nature of social life, that charity is a form of good karma that affects one's future circumstances and environment, and that good charitable deeds leads to good future life because of the reciprocity principle. Other Hindu texts, state that reciprocity may be innate in human nature and social functions but dāna is a

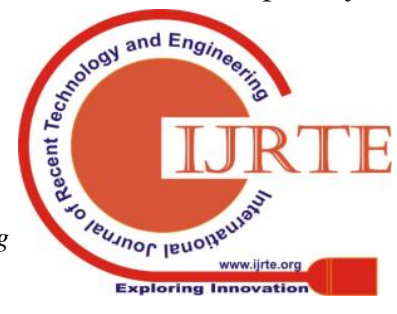


virtue in itself, as doing good lifts the nature of one who gives. The texts do not recommend charity to unworthy recipients or where charity may harm or encourage injury to or by the recipient. Dāna, thus, is a pious act, requires idealistic-normative approach, and has spiritual and philosophical context. The donor's intent and responsibility for diligence about the effect of dāna on the recipient is considered as important as the dāna itself. While the donor should not expect anything in return with dāna, the donor is expected to make an effort to determine the character of the recipient, likely return to the recipient and to the society.[16] Some medieval era authors state that dāna is best done with sraddha (faith), which is defined as being in good will, cheerful, welcoming the recipient of the charity and giving without anasuya (finding faults in the recipient). Charity is most effective when it is done with delight, a sense dāna means giving, often in the context of donation and charity. Dāna is related to and mentioned in ancient texts with concepts of Paropakāra which means benevolent deed, helping others; Daksinā which means gift or fee one can afford, and Bhiksha which means alms. Dāna has been defined in traditional texts as any action of relinquishing the ownership of what one considered or identified as one's own, and investing the same in a recipient without expecting anything in return. While dāna is typically given to one person or family, Hinduism also discusses charity or giving aimed at public benefit, sometimes called utsarga. This aims at larger projects such as building a rest house, school, drinking water or irrigation well, planting trees, and building care facility among others. Ethical values are the universal appeal of Purānas to extend peace, harmony, compassion and love in the society. These values regulate the behaviour of human conduct in a right way. Undoubtedly these are the very powerful tools aimed at the moral and spiritual upliftment of the people. These are used in different ways as a weapon against all evil deeds. It is regarded as the best form of dharma which promotes the high ideal of human values. Freedom from malice, absence of covetousness, control of the senses, austerity, celibacy, compassion, truthfulness, vrata , dāna, forbearance, fortitude etc., are the ethical values reflected in the Garuḍapurāna . After observing the rules laid down for Dānadharma it can be given the highest place among all the Samikāras which a Hindu should obey throughout his life and the Garuḍapurāna occupies an important position among all the Purāṇas while promoting Dānadharma for uplifting of individual as well as social life of the people.

\section{FOOTNOTES}

1. śabara on Jaimini Sūtras, iv.2.28

2. '...... dānamekam kalau yuga|

$$
\text { Manusmriti.1.86 }
$$

3. Dānam tu kathitam tajjñairbhuktimuktiphalapradam || Garuḍa Purāṇa 1.51.2 (a)

4. Yājñavalkyasmriti, iii.266-267,

Manusmriti, xi.128, 130-131, 134-140

5. Yaddīyate tu pātrebhyastadānam parikīrttim \|

Nityam naimittikam kāmyam vimalam dānamīritami || Garuḍa Purāṇa 1.51.4

6. Ibid.1.51.5-8

7. Dānakālam pravakṣyāmi nityanaimittikam nṛpa kāmyañcāpi mahārāja caturtham prāyikam punạ̣ \| Padma Purāṇa, Bhūmi khaṇḍa, 39.49

8. P.P. Bhūmi khaṇḍ, 14.20

9. Agnipurāṇa, 175.12-17.

10. Bhāgavatapurāṇa 8.19.36

11. Bhagavtagitā 17.20

12. BG 17.21

13. BG 17.22

14. Garuḍapurāṇa, 1.51 .12 (a), 16 (a), 30, 31 (b)

15. Ibid.1.51.98

16. Ibid.1.98.1-4

17. Ibid.1.51.9

18. Ibid. $1.51 .10-11$

19. Ibid.1.51.12-13

20. Ibid.1.51.15-16

21. Ibid.1.51.22

22. Ibid.1.51.23

23. Ibid.1.51.25 (b)

24. Ibid.1.99.13

25. "bhūmidānātparam dānam na bhūtam na bhaviṣyati |" GP, 1. 51.10(a)

\section{REFERENCES}

A. ORIGINAL WORKS

[1]. Śrimadbhāgavata, I, II, III Skandhas, Bhaktivedānta book Trust, Calcutta, 19

[2]. Śrimadbhāgavatamahāpurānam, Eng. tr. by Manmatha Nath Dutt, Eastern Book Linkers, Delhi, 2009.

[3]. Śrimadbhāgavata - Mahāpurāṇam with Śridhara Swāmi's commentary, ed. by Pandit Ramtej Pandeya, Delhi, 2011.

[4]. Bhāgavata Purānam, ed. by Jagadishlal Sastri, Matilal Banarsidass, Delhi, 1983

[5]. Brahmavaivarta Purāṇa, ed. by Jagadishlal Sastri, Matilal Banarsidass, Delhi, 2004

[6]. Brahmāṇṇa Purāṇa, ed. by Jagadishlal Sastri, Matilal Banarsidass, Delhi, 1987

[7]. Garuḍa Purāṇa, ed. by Acharya Pañchānan Tarkaratna, Nababharat Publishers' Reprint, Kolkata, 1416

[8]. Garuḍa Purāna, ed. by R.N. Sharma, Nag Publisher's, 3rd edit. Delhi, 2004

[9]. Garuḍa Purāna- A Study by N. Gangadharan, All India Kashiraj Trust, Varanasi, 1972

[10]. Garuḍa Purānam, Ancient Indian Tradition and Mythology, Vol-12, Part-1 Matilal Banārsidāss, Delhi, 1978

[11]. Manusamihitā, tr. by Kiran Sarma, Veda Vidyalaya, Guwahati, Asom, 1998

[12]. Matsya Purāṇa, ed. by Pañchānan Tarkaratna, Nababharat Publishers, Calcuttta, 1316 B.S.

[13]. Padmapurānan- A Study by Asoka Chatterjee. Published by- The Principal, Sanskrit College, Bankim Chatterjee street. Calcutta 1967.

[14]. Padma Purāṇa, (Sṛ̦ți, Bhūmi, Svarga, Brahma, Pātāla, Uttara and Kriyāyogakhaṇạa) ed. by Panchanan Tarkaratna, Calcutta, Nababharat Publishers, 1396 B.S

[15]. Padma Purāṇa, (Uttara Khaṇda), Calcutta, Gurumandal Series, 1959.

B. MODERN WORKS

[1]. Acharya, K. Tripathi, Paurāṇika Viṣayānukramanikā, Chowkhamba Surabharati Prakashan, 1ST edit. Varanasi, 1980 
[2]. Banerjee, S.C. Studies in the Mahāpurāṇas, Punthi Pustak, Kolkata, 1991

[3]. Banerjee, M. Invitation to Hinduism, Arnold-Heiemann publishers, New Delhi, 1978

[4]. 4. Bernard, Theos, Hindu Philosophy, Delhi, Matilal Banarsidass, 1999

[5]. Bhagavati, Ghana Kanta, The Bhāgavata Purāna- A Socio-Cultural Study, Vohra Publishers \& Distributors, Allahabad, 1988

[6]. Bhattacharyya, Narendra Nath, History of Indian Cosmological Ideas, Munshiram Manoharlal, New Delhi, 1971

[7]. Bhattacarya, Siddhesvara, The Philosophy of the Śrimad-Bhāgavata, Vol-I, Visva-Bharati Santiniketan, Calcutta, 1960

[8]. Chennakesavan Sarasvati , A Critical Study of Hinduism Motilal Banarsidass, 1974

[9]. Dange, Sadasiva Ambadas, Encyclopaedia of Puranic Beliefs and Practices, Vol-I(A-CO, Navarang, New Delhi, 1986.

[10]. Goyal, S.R. A Religious History of Ancient India Kusumanjali Prakashan, Meerut, 1986

[11]. Hazra, R.C. Studies in the Purānic Records on Hindu Rites and Customs, Matilal Banarsidass, 2nd edit., Delhi, 1975

[12]. Kanal S. P The Philosophy of Religion Lotus Publishers, New Delhi, 1984

[13]. Kane ,Pandurang Vaman History of Dharmaśāstra Vol. ii, Part ii , Bhandarkar Oriental Research Institute, Poona, 1974

[14]. Layle, P.G. Studies in Devi Bhāgavata, Popular Prakashan, Bombay, 1973

[15]. 15. Macdonell, Arthur A. History of Sanskrit literature, Appleton, New York, 1900

[16]. 16. Prasad, Ramanuj, Know the Purāṇas, Pustak Mahal, Delhi, 2009

[17]. 17. Pruthi, Rajkumar, An Introduction to Purānas, UBS Publications Distributors Pvt. Ltd., New Delhi, 2005

[18]. 18. Rukmani, T.S. A Critical Study of the Bhāgavata Purāna, Chowkhamba Sanskrit Series Office, Varanasi, 1970

[19]. 19. Pandey Rajbali, Hindu Samskãras, By Motilal Banarsidass, 1969

[20]. 10. P. Vora Dhairyabala, . Evolution of Morals in the Epic , Lamington Road, Bombay -7, 1960

[21]. 11. Sastri Haragovinda,( ed. By) Amarakosa of Amarasimha, Pt Chowhamba Sanskrit Series (CSS), Varanasi, 1970.

[22]. 12. Shastri, Puspendra, Introduction to Purāṇas, Rāstriya Sanskrit Sansthān, New Delhi, 1995

[23]. 13. Singh, Nag Sharan, An Introduction to Purāṇas, Nag Publishers, 1st edit., Delhi, 1985

[24]. Vaidya, C.V. History of Sanskrit Literature, (3 Vols Set) Parimal Publication, Delhi, 2005

[25]. Vyas, Ramnarayan, The Synthetic Philosophy of the Bhāgavata, Meharchand Lachmandas, Daryaganj, Delhi, 1974

[26]. Winternitz, M. A History of Indian literature, Vol. I, Matilal Banarsidass, Delhi, 1981

C. ENCYCLOPAEDIA, DICTIONARIES AND JOURNALS

[1]. A Sanskrit Dictionary, Monier Williams, Delhi, Matilal Banarsidass, 2002

[2]. Encyclopedia of Indian Philosophy, Vol. IV. G.J. Lardon, R. Bhattacharya \& K.H. Potter, Delhi, Matilal Banarsidass, 2010

[3]. Encyclopedia Religion and Ethics, Vol. IV, VI, VIII, X, James Hastings, Edinburgh: T\& T Clark, 1908

[4]. Purāṇic Encyclopedia, Vettam Moni, Delhi. Matilal Banarsidass, Reprint 1984

[5]. The Cultural Heritage Of India, Vol. II, ed. by S.K. De, U.N. Gosh, A.D Pusalkar and R.C. Hazra, Calcutta, Ramkrishna Mission of Culture, 2000

[6]. Sanskrit English Dictionary, Vaman Shivram Apte, Delhi, Matilal Banarsidass, 1970 